\title{
Possibility of affecting the casting structure of magnesium alloys
}

Petr Lichý, Jaroslav Beňo, Michal Cagala

Department of Metallurgy and Foundry, VSB - Technical University of Ostrava, 17. listopadu 15/2172, 70833 Ostrava

- Poruba, Czech Republic. petr.lichy@vsb.cz

Magnesium alloys belong to materials, which are nowadays more and more often used for various technical applications. Their principal advantage consists in their low specific mass and high specific strength, while their drawbacks consist, among other, namely in low mechanical properties at higher temperatures. Obtaining of fine grained structure can be achieved by high cooling effect of the mould. This can be ensured by use of metallic mould, especially in combination for example with die casting, or with low-pressure casting or gravity casting. Some other casting procedures exist, however, such as casting into expendable moulds, the cooling effect of which is substantially weaker. In these cases it is necessary to achieve the fine grained structure in another way. In this case an important role can be played by inoculation of material, i.e. addition of suitable nuclei. This paper deals with the influence of the inoculation on microstructure and thermo-mechanical properties of castings based on selected magnesium alloys.

Keywords: magnesium alloys, thermo-mechanical properties, microstructure, inoculation

\section{Acknowledgement}

This work was elaborated within the frame of the research project TA02011333 (Technology Agency of the CR), the internal project of VŠB-Technical university of Ostrava SP2013/62 and project No. CZ.1.05/2.1.00/01.0040 „Regional Materials Science and Technology Centre“, under the frame of the operation programme ,Research and Development for Innovations", financed by the Structural Funds and by the state budget of the Czech Republic.

\section{References}

[1] DRAPALA, J.; KUCHAR, L.; TOMASEK, K.; TROJANOVA, Z. (2004). Magnesium, its alloys and Mg - admixture binary system. VŠB -TU Ostrava, 2004, 172 p. ISBN 80-248-0579-0.

[2] MORDIKE, B. L.; EBERT, T. (2001). Magnesium properties - applications - potential. Materials Science and Engineering A, Vol. 30, No.1, pp. 37-45.

[3] ROSKOSZ, S.; ADAMIEC, J.; BLOTNICKI, M. (2007) Influence of delivery state quality on microstructure and mechanical properties of as cast AZ91 Mg alloy. Archives of Foundry Engineering, Vol. 7, No. 1, pp. 143-146.

[4] VOJTECH, D., KUBASEK, J., VODEROVA, M. (2012). Structural, mechanical and in vitro corrosion characterization of as temporary biodegradable medical implants. Manufacturing Technology, Vol. 12, No. 13, pp. 292-296.

[5] ZHANG, W., SHEN, Y., PAN, H., LIN, K., LIU, X., DARVELL, B. W., HUANG, W. (2011). Effects of strontium in modified biomaterials. Acta Biomaterialia, Vol. 7, No. 2, pp. 800-808.

[6] BŘUSKA,M. at al. (2013): Influence of repeated remelting of the alloy RR.350 on structure and thermo-mechanical properties, Manufacturing Technology, Vol. 13, No. 1, pp. 31-35.

[7] KUBOTA, K., MABUCHI, M., HIGASHI, K. (1999). Processing and mechanical properties of fine-grained magnesium alloys. Journal of Materials Science, Vol. 34, No. 10, pp. 2255-2262.

[8] ST JOHN, D. H.; QIAN, M.; EASTON, M. A.; PENG CAO; HILDEBRAND, Z. (2005). Grain Refinement of Magnesium Alloys, Metallurgical and Materials Transactions A, Vol. 36, No. 7, pp. 1669-1679.

[9] ZENG, X., WANG, Y., DING, W., LUO, A. A., \& SACHDEV, A. K. (2006). Effect of strontium on the microstructure, mechanical properties, and fracture behavior of AZ31 magnesium alloy. Metallurgical and Materials Transactions A: Physical Metallurgy and Materials Science, Vol. 37, No. 4, pp. 1333-1341.

[10] LEE, Y. C., DAHLE, A. K., STJOHN, D. H. (2000). The role of solute in grain refinement of magnesium. Metallurgical and Materials Transactions A: Physical Metallurgy and Materials Science, Vol. 31, No. 11, pp. 2895-2906.

[11] LICHÝ, P., BEŇO, J., CAGALA, M. (2013). Inoculant Addition Effect on Thermomechanical and Thermophysical Properties of Mg-Sr Magnesium Alloy, Manufacturing Technology, Vol. 13, No. 1, pp. 64-67.

[12] GREER, A. L., BUNN, A. M., TRONCHE, A., EVANS, P. V., BRISTOW, D. J. (2000). Modelling of inoculation of metallic melts: Application to grain refinement of aluminium by Al-Ti-B. Acta Materialia, Vol. 48, No. 11, pp. $2823-2835$. 